\title{
From Unsuccessful Attempts by Non Medical Personal to Surgery in Removing Rectal Foreign Bodies: Case Report
}

\author{
Hastanın Kendi Kendine Çıkarma Girişimi Başarısız Olması Nedeniyle Cerrahiye \\ Giden Rektal Yabancı Cisim: Olgu Sunumu
}

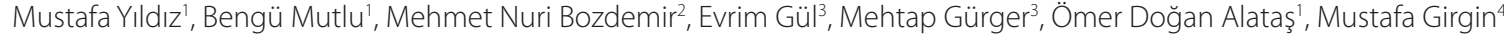 \\ 'Department of Emergency Medicine, Faculty of Medicine, Firat University, Elazığ, Turkey \\ 2Department of Emergency Medicine, Antalya Numune Education and Research Hospital, Antalya, Turkey \\ ${ }^{3}$ Department of Emergency Medicine, Elazığ Numune Education and Research Hospital, Elazığ, Turkey
}

${ }^{4}$ Department of Surgery, Faculty of Medicine, Firat University, Elazığ, Turkey

\section{ABSTRACT}

Intentional or unintentional insertion of foreign objects into the anus and rectum is a well-described phenomenon. A 40 year old man and 35 year old man presented to the emergency department after insertion of a high pressure container of tanning spray and insertion of a soda pop bottle into their rectum respectively. After an unsuccessful attempt to extract the foreign body at home, one patient tried to remove the foreign body by a piece of string which also stayed in the rectum. The foreign body was grasped with clamps and gently extracted in one case. In the other case, the foreign bodies were removed after sphincterotomy. To the best of our knowledge this is first case involving an attempt to remove the foreign body by a piece of string. We consider that removing a foreign body using string may involve a high risk of perforation, haemorrhage and infection. We describe two cases who presented at the emergency department with a rectal foreign body.

Keywords: Foreign body, rectum, string Received: 30.11.2011 Accepted: 24.04.2012

\section{ÖZET}

Kasıtlı veya kasıtsız anüs ve rektum içine bir yabancı cisim iyi tanımlanmış bir fenomendir. Kırk ve 35 yaşındaki iki erkek hasta, sırasıyla kendi rektumları içerisine sırasıyla yüksek basınçlı sprey şişesi ve soda şişesi yerleşimi nedeniyle acil servise başvurdu. Bir vakamızda hasta evinde yabancı cisim olan soda şişesini çıkarmak için tel ile uğraşmasına rağmen çıkaramamış ve yabancı cisim rektumda kalmıştır. Yabancı cisim klemple yakalanıp çıkarılmıştır. Diğer vakada sfinkterotomi sonrası yabancı cisim çıkarıımıştır. Bilebildiğimiz kadarıyla vakamız tel ile yabancı cismi çıkarma çabası ile ilgili ilk vakadır. Tel ile yabancı cismin çıkarılması çabasının perforasyon, kanama ve enfeksiyon için yüksek risk taşıdığını düşünüyoruz. Rektal yabancı cisim nedeniyle acil servise başvuran iki olguyu sunduk.

Anahtar Kelimeler: Yabancı cisim, rektum, tel

Geliş Tarihi: 30.11.2011 Kabul Tarihi: 24.04.2012

\section{Introduction}

Although intentional or unintentional insertion of foreign bodies into the anus and rectum are regarded as an uncommon phenomenon, it has commonly reported during recent years (1-3). Numerous foreign bodies may be inserted for diagnostic or therapeutic purposes, for self-treatment of anorectal disease, by criminal assault, by accident, or most commonly, for sexual purposes $(2,4-6)$.

The foreign bodies include soda pop bottles, tanning spray, glass or plastic bottles, beer bottles, tea cups, umbrella handles, wooden rectal dilators, test tubes, rectal tubes, cucumbers, carrots, bananas, vibrators, and rubber objects $(2,4)$. 


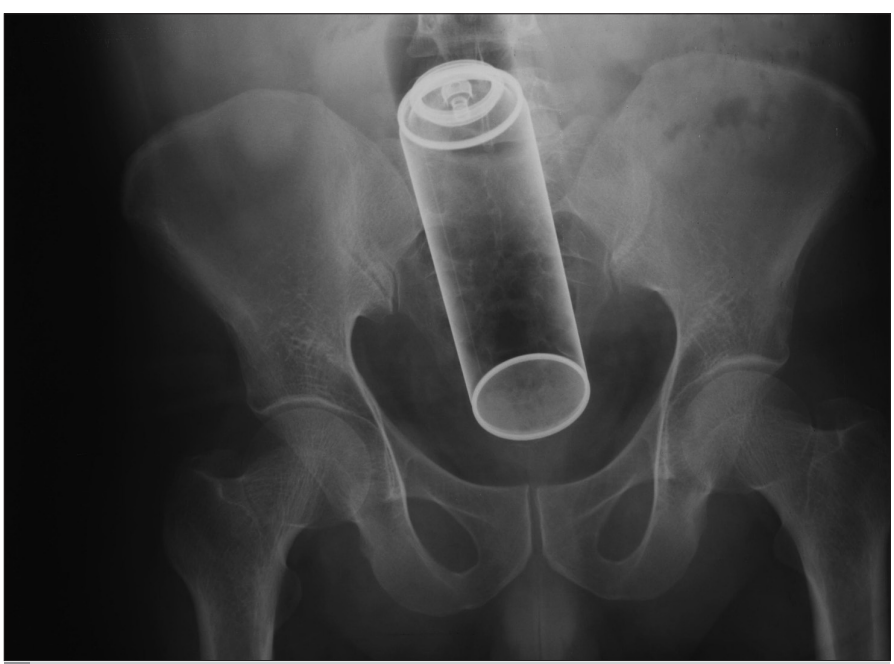

Figure 1. Plain abdominal radiography shows a high pressure container visible in the rectosigmoid region

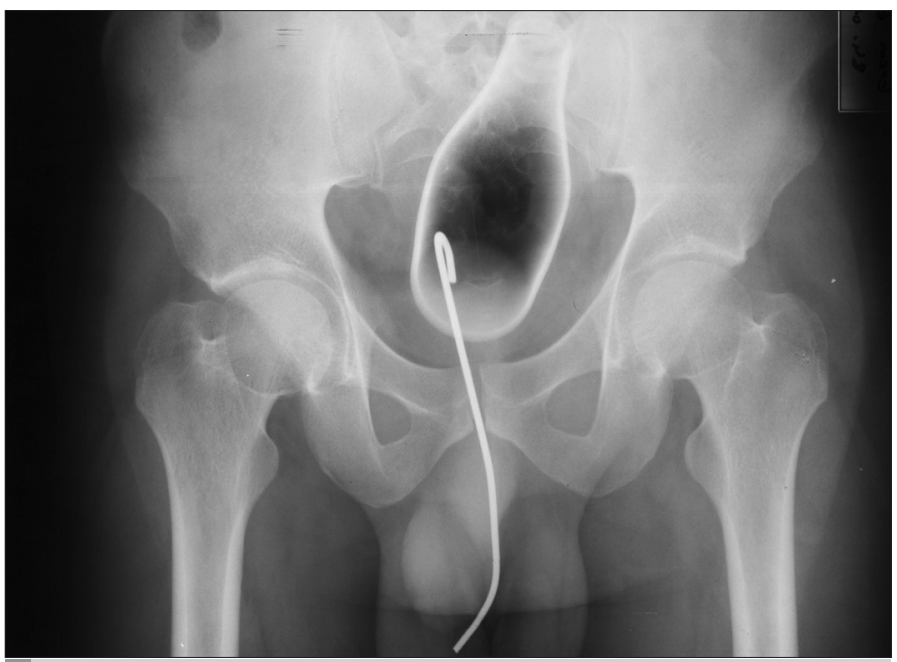

Figure 2. Plain abdominal radiography shows a soda pop bottle and string in the rectosigmoid region

Most patients with rectal foreign bodies usually present to the emergency room after efforts to remove the object at home. However, these efforts may worsen the situation (4). We present two cases to draw attention to the risk that unsuccessful attempts to remove a rectal foreign body by non medical personal may result in surgery.

\section{Case Reports}

\section{Case 1}

A 40 year old man presented to the emergency department three hours after inserting a high pressure container with tanning spray into his rectum. He said that a high pressure container with tanning spray was introduced transanally after tumble into his. He had no anorectal or abdominal pain and no anorectal haemorrhage. After unsuccessful attempts to extract the foreign body at home, he presented to the emergency department.

The initial vital signs were normal during presentation. On physical examination, the patient seemed well and did not reveal any signs of trauma. Abdominal examination was normal. Inspection of the perianal area did not reveal any signs of trauma, and no anal sphincteric abnormality. On rectal examination, there was a palpable object in the anorectal canal. On upright chest $x$-ray there was no evidence of extraluminal air. On x-ray of the pelvis, a high pressure container was visible in the rectosigmoid region (Figure 1).

The patient was taken to the operating room of emergency department. He was placed in a knee-chest position. The foreign body was visualised, grasped with clamps and gently extracted. After extraction, inspection of the perianal area did not reveal any signs of trauma, and no anal sphincteric abnormality was noted. His abdomen was soft. The patient was discharged after the extraction.

\section{Case 2}

A 35 year old man presented to the emergency department with anorectal pain 13 hours after inserting a soda pop bottle into his rectum. He failed to extract the foreign body by himself at home. He subsequently tried to extract it using a piece of string but the string was fully inserted into the rectum and stayed there.

He suffered from anorectal pain but not abdominal pain and denied the presence of an anorectal haemorrhage. The initial vital signs were normal during the presentation and there were no signs of trauma on physical examination. The abdominal examination was normal and the inspection of the perianal area did not reveal any signs of trauma, with normal anal sphincteric function. On rectal examination, there was a palpable object in the anorectal canal.

The $x$-ray revealed a radio-opaque soda pop bottle and string in the rectosigmoid region (Figure 2 ). The patient consulted with a surgeon and was hospitalised in the surgery ward. The foreign body was removed in the lithotomy position after sphinctoromy under general anesthaesia. Post-removal, rectal examination and endoscopy did not reveal any colorectal injury except for mucosal oedema. Although we preferred to follow the patient in order to detect a possible peritoneal irritation and perform a control endoscopy, the patient did not accept our suggestion that he should stay in hospital and he discharged himself.

\section{Discussion}

Diagnosis of rectal foreign bodies is usually made by evaluation of medical history, digital examination of the rectum, direct abdominal radiography, sigmoidoscopy and roentgenography (7-9). Anamnesis may include anorectal pain and rectal bleeding (proctorrhagia), reported in $66.6 \%$ of cases, and difficulty in passing stools (dyschezia). Unsurprisingly, a history of anal introduction is given only in $33.3 \%$ cases. In rare cases, abdominal tenderness, presence of fever and signs of peritonitis suggest the possibility of a perforation (8). Our patients presented to the emergency department with a history of anorectal pain.

Rectal examination usually identifies the presence of a foreign body in the distal rectum. A foreign body above the rectosigmoid junction may not be palpable. Rectal examination and anoscop- 
ic evaluation can reveal an injury to the anal canal or sphincter mechanism (8).

Foreign bodies can be removed either at home by the patients and or in the hospital. Patients may be reluctant to seek healthcare assistance because of socioeconomic, religious or cultural reasons. Therefore, they usually try to extract the foreign body by themselves at home and present to the emergency department if they fail (4).

A string insertion to extract a foreign body from the rectum has not previously been reported in the medical literature. However, usage of a string may confer a risk of perforation, haemorrhage and infection. In the second case reported here, due to the risk of complication, the removal procedure was performed in the operating room rather than emergency department.

Most foreign bodies in the rectum should be removed transanally and the majority of objects are easily removed in the emergency department $(7,8,10)$. In a patient without complications, the therapeutic algorithm typically begins with sedation and a bedside attempt for extraction in the emergency department.

There are a few basic principles in removing a foreign body transanally. The first rule is that the object has to be within reach of the fingers or a clamp to obtain an adequate grasp on the object. In addition, a conscious patient may be able to assist with Valsalva manoeuvres. If the object is not palpable on rectal examination, aggressive attempts at extraction in the emergency room should not be made and cathartics should not be used (8).

In this case, the patient is transferred to the operating room for full relaxation of the anal sphincter muscles. This can be achieved by local, spinal, or general anesthaesia (10). In rare cases, a sphincterotomy may be required for anal dilatation (8). These techniques are usually successful; a laparotomy is required in less than $10 \%$ of patients (11). The second case in the present article required surgical treatment under general anesthaesia with sphincterotomy.

\section{Conclusion}

All patients should be observed to exclude a rectal perforation following successful extraction. Anal incontinence may be a problem but there is little information on its incidence following extraction (7). The bowel wall should be checked after the extraction with an endoscope and the patient should keep under observation for 48 hours (3). However, the cases described here did not accept this recommendation. Additionally, all patients should be referred for psychological evaluation to avoid similar problems in the future and to minimise psychological trauma in assault cases (8).

\section{Conflict of interest}

No conflict of interest was declared by the authors.

\section{References}

1. Akhtar MA, Arora PK. Case of unusual foreign body in the rectum. Saudi J Gastroenterol 2009; 15: 131-2. [Crossref]

2. El Musharaf HA. Ano-rectal foreign body: A case report. Saudi J Gastroenterol 1997; 3: 103-4.

3. Andrabi SI, Johnson NA, Malik AH, Ahmed M. Extraction of a rectal foreign body - an alternative method. Ulus Travma Acil Cerrahi Derg 2009; 15: 403-5.

4. Clarke DL, Buccimazza I, Anderson FA, Thomson SR. Colorectal foreign bodies. Colorectal Dis 2005; 7: 98-103. [Crossref]

5. Lee KF, Wong J, Lai PB. Radiolucent foreign body visible on plain radiography. Can J Surg 2008; 51:87-8.

6. Koornstra JJ, Weersma RK. Management of rectal foreign bodies: Description of a new technique and clinical practice guidelines. World $J$ Gastroenterol 2008; 14: 4403-6. [Crossref]

7. Rodriguez-Hermosa JI, Codina-Cazador A, Ruiz B, Sirvent JM, Roig J, Farres R. Management of foreign bodies in the rectum. Colorectal Dis 2007; 9: 543-8. [Crossref]

8. Memon JM, Memon NA, Solangi RA, Khatri MK. Rectal foreign bodies. Gomal Journal of Medical Sciences 2008; 6: 1-3.

9. Lowicki EM. Accidental introduction of giant foreign body into the rectum: Case report. Ann Surg 1966; 163: 395-8. [Crossref]

10. Santhat N, Dan RM, Mark DS. A simple technique to remove a large object from the rectum. J Am Coll Surg 2006; 203: 132-3. [Crossref]

11. Ball CG, Wyrzykowski AD, Sullivan P, Feliciano DV. Intussuscepted intestine through a rectal foreign body. Can J Surg 2009; 52: 191-2. 